\title{
Pentecostalismo e empoderamento de identidades marginalizadas
}

\section{Pentecostalism and empowerment of marginalized identities}

\section{David Mesquiati de Oliveira, Alessandro Rocha*}

Faculdade Unidade de Vitória (UNIDA), Vitória, ES, Brasil

\section{Resumo}

$\mathrm{O}$ artigo aborda o tema do pentecostalismo privilegiando a margem (social e eclesial) como lugar de tomada de consciência, a partir das contribuições de Gilbert Durand. Busca descobrir a possibilidade de encontro dos centros da vida mesmo quando se está ainda à margem da sociedade, para, a partir desse lugar, dirigir-se ao centro dos processos sócio-eclesiais. Ao final, pondera-se sobre as potencialidades do sacerdócio de todos os cristãos como elemento de pro-vocação que vem desde os lugares (teológicos) marginais, tomando como ponto de partida histórias de vida de dois personagens - um negro e pobre, e a outra uma imigrante -, do pentecostalismo clássico.

Palavras-chave: Pentecostalismo. Marginalização. Teoria do imaginário. Gênero. 
Abstract

The article deals with the theme of Pentecostalism, privileging the margin (social and ecclesial) as a place of conscience, based on the contributions of Gilbert Durand. It seeks to discover the possibility of meeting the centers of life even when one is still on the margins of society, in order to move from that place to the center of socio-ecclesial processes. In the end, the potential of the priesthood of all Christians is considered as an element of pro-vocation that comes from the marginal (theological) places, taking as starting point life stories of two characters - one poor and black and the other an immigrant woman - of classical Pentecostalism.

Keywords: Pentecostalism. Marginalization. Imaginary theory. Gender.

\section{Introdução}

O século XX foi o palco de grandes e profundas transformações societárias. Do ponto de vista epistemológico, a razão forte ancorada no racionalismo mecanicista viu-se questionar por uma razão fraca, amplamente aberta à experiência como forma de percepção da realidade. Uma nova configuração do poder surgiria, dando espaço ao estético e a inúmeras formas de representação da realidade a partir de hermenêuticas particulares.

No que diz respeito ao cristianismo em suas várias tradições é preciso destacar aqui a emergência dos pentecostalismos que acabou por se constituir numa resposta de vanguarda às profundas mudanças na civilização ocidental. Num mundo de mudanças de paradigmas, onde os centros de poder sofreram duras críticas, surgiu das margens mais improváveis, uma força espiritual capaz de desafiar as organizações sócio-teológico-eclesiais do Ocidente.

Seguindo a intuição de que das margens do mundo emergem novos elementos capazes de renovação, percorreremos, nesse artigo, sobre o pentecostalismo o seguinte caminho: a margem como lugar de tomada de consciência; descobrindo os centros da vida mesmo que ainda à margem 
da sociedade; das margens da margem ao centro da margem e com a cabeça no centro; por um centro com cara de margem.

\section{A margem como lugar de tomada de consciência}

Tomaremos o conceito de "margem" numa perspectiva teórica e, mais especificamente, dentro do universo conceitual de Gilbert Durand. O antropólogo francês Durand, de enorme importância no âmbito dos estudos sobre teoria do imaginário, afirma que "nenhuma situação social, mesmo a mais marginalizada pode ser reduzida à inércia pelo imaginário. O que acontece, ao contrário, é um reforço dinâmico da marginalidade do imaginário" (DURANT, 1996, p. 159). Desta forma, Durand potencializa uma leitura da marginalização como lugar fértil para a emersão do novo, daquilo que pode fecundar a realidade para novos momentos e projetos. $\mathrm{O}$ elemento que Durand percebe como potencializador do que se encontra à margem é o imaginário. Aquilo que ele chama de "ciência do imaginário" (DURAND, 1998, p. 77), ou seja, uma abordagem à realidade que valoriza o universo dos símbolos e mitos como elementos de ordenação, desordenação e reordenação social.

O imaginário é um lugar de "entre saberes" (DURAND, 1996, p. 215s.) que cria um tipo de cultura do imaginário. Esta cultura se mostra nas imagens que são produzidas, transmitidas e recebidas na sociedade. Na concepção durandiana, o imaginário é um organismo dinâmico, um lugar de todas as imagens, um tipo de "museu" que expõe, conserva e apresenta imagens de diferentes tempos e lugares. Outra analogia durandiana é a da "bacia semântica", que evoca os movimentos hídricos alimentados pelos fluxos e correntezas diversas, em que, no "trajeto antropológico", o sujeito bebe das águas e cria seus próprios lagos (DURAND, 1996).

A partir desse pensamento de Durand é possível dizer que os grupos marginalizados, que dentre outras coisas se encontram à margem dos saberes racionalistas, têm na teoria do imaginário o conjunto de elementos necessários para a leitura de suas realidades, bem como para a respectiva compreensão e superação da lógica perversa que os dominam. Essas observações de 
Durand encontram sua maior expressão e dinamismo no universo do homo religiosus. Sendo um habitante de um universo ricamente simbólico, o homo religiosus é capaz, mesmo estando à margem da sociedade, de ler sua realidade com outras chaves e, reelaborar sua experiência e história.

Em função da riqueza do pensamento de Durand, bem como sua pertinência para a abordagem que aqui fazemos de um extrato do mundo religioso, este que tem sua origem e boa parte da sua história à margem das sociedades que o viram crescer (pentecostalismo), elencamos dois importantes argumentos que nos possam orientar na trajetória da valorização do lugar da margem como berço acalentador do novo que queremos colher para possíveis inspirações teológicas.

O primeiro argumento da teoria do imaginário de Durand é a ligação entre os marginalizados e seu imaginário para sair desta situação: as "exclusões" na dinâmica social. Embora vivendo como todo mundo na sociedade, estas pessoas são excluídas pela classe dominante, vivem na sua margem. Eles experimentam a exclusão, a marginalização! Mas, "as margens" segundo Durand, são uma espécie de reserva cultural e social, enquanto que os "senhores" do tempo constituem a sociedade dominante. O marginalizado é o negativo absoluto, o rejeitado completo, aquele que não importa. Ora, é justamente este negativo que possui uma potência social tópica. Nenhuma situação social, mesmo a mais excluída é reduzida à inércia do imaginário (Cf. DURAND 1996, p. 159). Ao contrário, assistimos um reforço dinâmico da marginalidade através do imaginário.

O excluído entra, primeiro, como polo imaginário negativo, ameaçador, poluidor. Este reforço negativo, aos poucos, vai sendo colorido por elementos positivos. Durand cita a "moda" como exemplo: o que era desprezado considerado de mau gosto, de repente se valoriza, com o nome positivo de "retrô" e se torna uma antiguidade valorizada e colocada na vitrine (Cf. DURAND, 1996, p. 160). Agora, vivemos esta experiência com a moda dos anos 60 .

Cada sociedade tem seu habitus identificador, que no caso da sociedade brasileira é o catolicismo. E quando esta identificação se torna certeza, infunde uma segurança, este habitus se banaliza, e a outra parte se potencializa nas margens mitogênicas da cultura. Assim, o marginalizado de ontem pode tornar-se o dominante de hoje, isto depende de uma 
geração antropológica que consiga tomar outra posição. Levar a sério o imaginário parece ser uma renovação das ciências humanas e uma nova visão do mundo. "A representação dos excluídos" é uma parte fundante na gênese do imaginário social, significa uma voz indispensável no concerto de uma cultura e de uma sociedade.

O segundo argumento da articulação do Pentecostalismo com a teoria do imaginário está baseado na maior obra de G. Durand, As estruturas antropológicas do imaginário e sua teoria dos dois regimes do imaginário (DURAND, 2002, p. 65). Nela, Durand apresenta o regime diurno como masculino representado pela espada e pelo cetro, símbolos ativos, agressivos; em seguida, apresenta o regime noturno como feminino, representado pela taça, e pelo cofre, pelo vazio, símbolos passivos, de recepção. O mito do "progresso", que imperou durante toda a modernidade, é um símbolo guerreiro e conquistador, representava a penetração do mundo, mas, o autor reflete que agora, na pós-modernidade, será substituído pelo movimento de recepção representado pela taça, pelo vazio, pelo movimento de descida, processo que o sociólogo francês Michel Maffesoli chama de "ingresso"; entrada numa energia nova, uma sintonia emocional, num ambiente coletivo representado pelo "continente", símbolo feminino.

Esta é uma outra maneira de entender a criação, algo que não tem a violência da razão instrumental, mas se contenta em acompanhar o que cresce lentamente em função de uma razão interna (MAFFESOLI, 2003, p. 77). O pentecostalismo, que é caracterizado pela efusão do Espírito Santo, pelo "batismo no Espírito" (figura que aponta para a realidade de cada crente como "taça" que recebe o vinho novo), pode ser considerado do regime noturno. Durand afirma que o regime noturno está substituindo o diurno e, neste caso, uma religião que está neste regime seria mais aderente a este momento que nos toca viver.

Levar a sério o imaginário parece ser uma renovação das ciências humanas e uma nova visão de mundo. "A representação dos excluídos" é uma parte fundante na gênese do imaginário social e significa uma voz indispensável no concerto de uma cultura e de uma sociedade. Para o público em geral na atual sociedade, o poder gerador simbólico está atrelado a um tipo de imagem que é fornecido basicamente pela mídia, por meio da imprensa, fotografia, publicidade, TV, cinema, etc. (DURAND, 1996, 
p. 20s.), que sob muitos aspectos estão cooptados pelo centro, na tentativa de controlar as margens. Essa civilização da imagem, concentrada em imagens visuais em detrimento de imagens mais densas e reflexivas ou mesmo da natureza, deu vazão a uma inflação da imagem, sem que isso tenha redundado em novidade ou criatividade, pois a imagem banalizada sufoca o imaginário. Mais do que nunca, faz falta a observação das imagens que vem da natureza, do mundo ao redor e da produção humana até o momento, da imaginação, da crítica das imagens recebidas e inventariadas. Por isso, as margens das margens são muito importantes, elas não foram domesticadas pelo centro.

\section{Descobrindo os centros da vida mesmo que ainda à margem da sociedade: "Desvalorizados pelo mundo e eleitos de Deus"}

Na perspectiva da teoria de Durand, acerca da marginalização e do imaginário como instrumento capaz de impulsionar mulheres e homens da invizibilização marginal ao protagonismo dos processos de vida, passamos agora a uma aproximação de um dos vários grupos à margem da sociedade. De forma mais específica, nesse momento, tomamos o pentecostalismo em sua origem nos Estados Unidos da América (EUA). Queremos problematizar a seguinte questão: como os desvalorizados pelo mundo se compreendem como eleitos de Deus. Ou ainda, como é possível descobrir e se localizar nos centros de vida, quando ainda se está à margem dos processos sociais.

Nesta problematização, já está de alguma forma dito que, a partir da valorização do imaginário como forma de percepção da realidade e sua dinâmica, é possível criar um novo ordenamento para a vida que se encontra à margem sem que a opressão desta impere sobre aquela. Ou seja, subvertendo os valores ditados pelo racionalismo é possível construir uma vivência ainda nos espaços marginalizados, que antecipem de forma profética os valores que se encontram em maior evidência nos centros. Isso, no entanto, não se trata de glorificar a vida que se obriga à margem, mas perceber que é dali onde ela está que se pode começar um processo de reordenamento de toda a realidade. 
No intuito de evidenciar tal potencial da vida à margem, percorreremos o seguinte caminho em nossa leitura sócioteológica do pentecostalismo em suas origens: em primeiro lugar, reconstruiremos a geografia social do pentecostalismo, no sentido de evidenciar que esta se constitui no horizonte dos pobres; em segundo lugar, chamaremos a atenção para a centralidade da experiência, peculiaridade da gnosiologia própria a esse movimento de margem que tanto privilegia a lógica do imaginário; por último, veremos o quanto tal gnosiologia opera um reordenamento sócio-religioso que se evidencia na relativização das estruturas eclesiais hierárquicas. Desta forma, estaremos caminhando para o tópico seguinte onde trabalharemos a valorização do sacerdócio universal de todos os cristãos.

O pentecostalismo em sua origem tem uma geografia marcada pelos traços da pobreza, da discriminação racial e das grandes restrições de direitos sociais. Ele surgiu no início do século XX do movimento de "santidade", que por sua vez deve muito ao conceito wesleyano de perfeição cristã como uma segunda obra da graça, distinto da justificação. O berço de onde o pentecostalismo se levantou foi o das periferias dos Estados Unidos da América, a partir das experiências de William Seymour, um negro operário, na Escola Bíblica de Topeka, sob a direção do Pastor branco Charles Parham (ROCHA, 2003, p. 76).

Seymour, que só podia assistir da varanda da casa as exposições bíblicas de Parham, devido à sua cor, leva para a periferia de Los Angeles aquela mensagem que iria revolucionar a vivência da fé, sobretudo dos negros e pobres norte-americanos. Como observa Richard Shaull, o pentecostalismo foi uma resposta ao sofrimento dos pobres (SHAULL, 2000, p. 29).

Também Antônio Gouvêa de Mendonça e Prócoro Velasques refletem sobre esta íntima relação do pentecostalismo com as classes mais pobres da sociedade norte-americana, mas também a brasileira, chegando mesmo a apontar que o pentecostalismo - como de forma geral as religiões do Espírito - cumpre um papel que o cristianismo tradicional, católico e protestante não atenderia mais, o da promoção da justiça (MENDONÇA \& VELASQUES, 1990, p. 255-256).

O pentecostalismo gerou uma nova perspectiva teológica onde o Espírito é quem capacita os agentes religiosos para as diversas funções na Igreja. A novidade daquele movimento estava, porém, na condição destes 
agentes. Operários negros, mulheres e crianças foram se constituindo protagonistas na pregação e vivência eclesial do evangelho. Esse grupo foi se transformando no movimento de comunhão e cooperação em nível religioso, mas também social. Como diz Seymour acerca da ação do Espírito:

Houve mestres que ordenaram às pessoas, venderam o que tinham, e muitos tornaram-se fanáticos. Nós, todavia, deixamos o Espírito guiar os crentes e dizer-lhes o que ofertar. Quando alguém fica cheio do Espírito, a sua carteira se converte e Deus o torna mordomo. Se Deus lhe ordenar: Venda! Ele vende (SEYMOUR, 2001, p. 11).

Essa experiência de partilha e cooperação é fundamentalmente teológica, e para o pentecostalismo nascente, mais especificamente pneumatológica. Como narra Seymour, esse proto-teólogo da experiência pentecostal: "a verdadeira evidência de que o crente recebeu o batismo com o Espírito Santo, é o amor divino, que é a caridade” (SEYMOUR, 2001, p. 38).

Além da geografia marcada pela desigualdade social e racial, o pentecostalismo em sua origem marca também uma posição teológica (mesmo que não sistematizada em seus inícios) em face ao mundo religioso de seu tempo. Este era marcado, entre outras coisas, pelo racionalismo teológico de um lado e, pelo rigor litúrgico e o objetivismo doutrinário por outro. Diante de tal situação o pentecostalismo assumiu o protagonismo em tornar relevante a fé para grandes parcelas do povo, especialmente onde a carência na área social e o vácuo experiencial se mostravam de forma mais evidente.

Frente ao universo religioso protestante marcado por racionalismos críticos ou apologéticos, o pentecostalismo marca sua presença afirmando o lugar irredutível da experiência, que se apresenta como chave hermenêutica para a teologia e, que se evidencia nos dons carismáticos. Neles o crente é quem faz a mediação da palavra teológica sem uma necessária recorrência a um corpus doutrinário externo. Trata-se de uma racionalidade diferente, de uma racionalidade afetiva. Álvaro MárquezFernández (2014, p. 158) fala sobre uma "razão afetiva" que encontraria eco aqui. Para ele, a razão "não deveria, como se tem pretendido, permanecer isolada do sentimento, ao contrário, deveria nutrir-se dele. Só assim se poderia reverter o papel do domínio que a razão alcançou no sentir 
dos sentimentos". E acrescenta: "e cancelar o desalojamento anímico do qual tem sido objeto". Uma razão afetiva "parte do dado interior da experiência sentimental; isso é, aquilo que a constitui como algo invisível e inexplicável, mas que evidentemente faz parte do ser anímico e psíquico que se experimenta" (MÁRQUEZ-FERNÁNDEZ, 2014, p. 162). A partir disso, desse sentir ampliado, é possível construir uma nova episteme tanto dos sujeitos quanto dos sentimentos.

Torna-se necessário enfatizar alguns aspectos que essa centralidade da experiência gera na teologia e prática pentecostal. Para isso, recorremos a um texto do próprio Seymour onde afirma:

Cada filho de Deus deve buscar o seu pentecostes pessoal. Não é preciso lhe anuncie a doutrina do Batismo com o Espírito Santo e com fogo, pois você pode obedecer ao que Jesus diz: Onde estiverem dois ou três reunidos em meu Nome, aí eu estou no meio deles (Mt 18.20) (SEYMOUR, 2001, p. 36-37).

Esse acento na experiência difusa que se dá sem qualquer mediação necessária da Igreja institucionalizada possibilita ao pentecostalismo uma capacidade de mobilidade e penetração e, ao mesmo tempo, a possibilidade de que cada crente pentecostal faça a experiência pneumatológica e simultaneamente se torne seu próprio sistematizador. Oliveira \& Terra (2018) aprofundaram a reflexão sobre a importância do êxtase como locus dessa experiência pentecostal.

A centralidade da experiência no pentecostalismo acabou por exercer enorme incidência sobre a eclesiologia. Em primeiro lugar ocorreu uma expansão gigantesca que se deve em boa medida à que os cânones doutrinários objetivos são de menor importância, pois onde se dá a experiência com o Espírito, se dá também os elementos necessários para a vivencial eclesial. Radicalmente isso significa que cada fiel reúne todas as condições (dons espirituais) para exercer o ministério da pregação e, a partir daí formar grupos de vivência da fé com toda a dignidade eclesial.

$\mathrm{O}$ crente como aquele que experimenta e sistematiza a fé torna-se ao mesmo tempo objeto e sujeito na relação com o Espírito. A ideia de clero e laicato é amplamente relativizada nesse ambiente. Isso produz, além 
de outras coisas, uma enorme mobilidade, tanto eclesial quanto social, no interior do pentecostalismo.

No pentecostalismo se encontra o elemento relativizador das estruturas eclesiásticas de maneira mais evidente (ROCHA, 2008, p. 155). E isso não como rebeldia, mas como interpretação pneumatológica, ou seja, como compreensão da ação do Espírito na vida de homens e mulheres. O Espírito é quem toma o espaço no lugar das hierarquias e estas só são possíveis, se confirmadas por Ele (ROCHA, 2008, p. 157). A experiência com o Espírito é de tal forma elevada ao status hermenêutico que opera mesmo uma ressignificação do texto bíblico. Como observa Seymour:

Quão maravilhoso é termos o bendito privilégio de sermos cooperadores do Espírito Santo! Ele nos inspira com fé na palavra de Deus e dota-nos com poder para servir ao Mestre. Todo homem ou mulher que recebe o batismo com o Espírito Santo é a Noiva de Cristo. Eles têm um espírito missionário e pentecostal: O Espírito e a esposa dizem: Vem! E quem ouve diga: Vem! E quem tem sede venha; e quem quiser tome de graça a água da vida (Ap. 22.17) (SEYMOUR, 2001, p. 88).

A noiva não é mais a Igreja enquanto corpo, mas cada homem ou mulher que faz a experiência do Espírito. O ofício ministerial também é reinterpretado: "É o ofício do Espírito Santo presidir todo o trabalho de Deus na terra. Jesus [...] enviou o Espírito Santo para assumir o seu lugar - não os homens" (SEYMOUR, 2001, p. 119).

Percebe-se um deslocamento das estruturas teológicas objetivas, dos cânones doutrinários estritos para uma centralização da experiência de subjetividade, onde nem mesmo as estruturas eclesiais e o próprio texto bíblico passam incólumes de uma reinterpretação e até mesmo de uma ressignificação. O coração é o locus theologico, o ser humano é a noiva de Cristo e o Espírito é quem revela estas verdades.

Devemos reconhecer que o templo é apenas um lugar onde o povo de Cristo se reúne para cultuar. O Templo não é a Igreja, a Igreja está implantada em nosso coração pelo sangue de Jesus Cristo, pois Ele disse: Sobre esta pedra edificarei minha Igreja, e as portas do inferno não prevalecerão contra ela (Mt.16.18). Em cada assembleia, a primeira coisa a ser verificada é se o Espírito Santo está empossado como Presidente [...] Não que seja 
errado haver um homem na direção, mas tal indivíduo deve estar cheio do poder do Espírito (ROCHA, 2008, p. 137).

Na margem do mundo religioso e teológico de onde emergiu o pentecostalismo, mulheres e homens puderam fazer experiências de vida que a muito eram destinadas somente aos centros. Eles descobriram o centro da vida mesmo ainda estando à margem da sociedade. Desta descoberta, queremos destacar um elemento capaz de potencializar vários outros aspectos da vida eclesial e social: o sacerdócio universal de todos os cristãos.

\section{Das margens da margem ao centro da margem... e com a cabeça no centro. 0 caminho de afirmação do sacerdócio de todos os cristãos: Mulheres e Homens}

Do pentecostalismo norte-americano surgiram os primeiros agentes, homens e mulheres, para a promoção do pentecostalismo brasileiro. Poderíamos dizer que das margens do centro (EUA) o pentecostalismo chega às margens da margem (Brasil). Isso significa que ser margem na margem é ainda mais perverso do que ser margem no centro. Aqui, à margem da margem iniciou-se nos inícios do século XX o movimento que aos poucos desafiaria os centros - sobretudo os centros da fé — à vivência da maior radicalidade do evangelho, principalmente da igual dignidade de todas as pessoas.

Diversas faces dessa igualdade da dignidade humana estão contempladas na temática bíblico-teológica do sacerdócio universal de todos os cristãos: a superação do sacerdotalismo que aliena a vocação de todos os cristãos, a valorização dos pobres e a mobilidade social que ocorre a partir da vida eclesial, a inclusão dos negros nos quadros eclesiásticos de liderança etc. Contudo, dentre todos esses importantes aspectos, queremos salientar um dos mais importantes, ao mesmo tempo em que um dos menos investigados. A saber: a presença das mulheres na organização e na dinâmica da igreja. Faremos isso tomando como exemplo a vida e o ministério de Frida Vingren.

No início da igreja Assembleia de Deus (ADs) nos Estados Unidos, as mulheres foram muito importantes na difusão da nova experiência, porque juntavam pessoas nas suas casas para orar, aprofundar na 
espiritualidade e fazer experiência do "batismo no Espírito". Eram pastoras e missionárias. Além de serem mulheres (interdito ao sagrado) eram também negras, porque o Espírito Santo não faz acepção de pessoas. Pela experiência com Jesus todas as pessoas são vocacionadas a serem sacerdotes que anunciam o amor e a misericórdia de Deus. Este é o princípio do sacerdócio universal de todos os crentes. Lutero afirmava:

De posse da primogenitura e de todas as suas honras e dignidade, Cristo divide-a com todos os cristãos para que por meio da fé todos possam ser também reis e sacerdotes com Cristo, tal como diz o apóstolo Pedro em 1Pe 2.9 [...] Somos sacerdotes; isto é muito mais que ser reis ${ }^{1}$, porque o sacerdócio nos torna dignos de aparecer diante de Deus e rogar pelos outros (LUTERO, 2000, p. 444).

Não apenas os cristãos ordenados participam da missão, mas todos os membros das igrejas. Cada pessoa é chamada a este compromisso, pois todo trabalho humano é resposta a um chamado divino a serviço do povo de Deus. As mulheres então faziam a experiência do "batismo no Espírito" e começavam a anunciar. Esta novidade alvissareira, no entanto, não durou muito tempo. Nos EUA, o problema do racismo logo dividiu brancos e negros, e a questão de gênero logo se opôs à participação das mulheres. Portanto, a valorização dentro da igreja voltou a permanecer nas mãos dos homens.

Quando Daniel Berg e Gunnar Vingren vieram para Belém do Pará, (1910) não se faz menção ao trabalho das mulheres. Em 1917 chega a Belém uma jovem sueca, enfermeira, que veio para se casar com seu conterrâneo Gunnar Vingren (ALENCAR, 2009, p. 69). Ela se tornaria uma líder nas ADs no Brasil. Sua atuação criou uma série de problemas para os missionários suecos e pastores brasileiros, a tal ponto que a Convenção de 1930 toma a seguinte decisão: "as mulheres são proibidas de dirigir e

1 Antes da Reforma protestante já se havia proposto uma ampliação do sacerdócio universal, especialmente com John Wycliff e John Huss, mas em Lutero esse tema é retomado enfaticamente. Além disso, a posição dele não deixa de ter ambiguidades, pois escreve para a nobreza alemã evocando o sacerdócio universal, mostrando que eram mais que "reis", pois Lutero queria que os príncipes convocassem um concílio reformador à revelia do papa. No entanto, quando Thomas Müntzer apelou para o mesmo princípio do sacerdócio universal em sua igualde radical para que levasse a cabo uma reforma social em que os camponeses não tivessem mais que estar absolutamente inferiorizados em relação aos nobres, Lutero recua, percebendo 0 alto valor revolucionário dessa assertiva: sacerdócio universal. Ver mais em: OLIVEIRA, 2017 e BURGARD, 2013. 
ensinar na igreja: podem apenas testemunhar" (ALENCAR, 2009, p. 69). Isto nos revela, então, que elas dirigiam e ensinavam na igreja. E podemos afirmar que testemunhar não deixa de ser uma forma de ensinamento!

Frida viveu apenas treze anos no Brasil: sete em Belém e seis no Rio de Janeiro. Apesar do pouco tempo em que aqui permaneceu, deixou muitas marcas, embora a história oficial da igreja não a tenha reconhecido em seu momento. Era missionária, pregava, cantava, tocava instrumentos e compunha hinos. Existem 24 hinos registrados em seu nome na Harpa Cristã, sendo que alguns eram traduções. No Rio dirigia cultos na praça Onze, em presídios, nas casas e nos templos. Enquanto esteve em Belém, redigiu o jornal Boa Semente, e depois no Rio, o jornal Som Alegre, que posteriormente, em 1930 são unidos e nasce o Mensageiro da Paz (existente até hoje) e do qual foi redatora (ALENCAR, 2009, p. 69).

Em 1960 celebrou-se o cinquentenário da fundação da AD no Brasil. Nesta data, Berg e Vingren assumem a posição de fundadores "heroicos", porque a instituição precisava de "heróis" para se legitimar e legalizar. Afinal, toda instituição na sua origem tem seus heróis fundadores. Daniel Berg, em 1961, em solenidade no Maracanã recebe uma placa folheada a ouro, embora nos anos anteriores, segundo relatos de contemporâneos, tivesse vivido em grande pobreza, esquecido, e abandonado na periferia de São Paulo (ALENCAR, 2009, p. 71).

Desde 1913, quando são consagrados 5 pastores brasileiros, e entre 1910 e 1930 quando chegam ao Brasil mais de 30 suecos, começa a luta entre estes e os fundadores. Gunnar Vingren é valorizado neste momento, mas fora voto vencido em diversas questões discutidas nas ADs de sua época. Além de ser uma pessoa doente, assim que chegou a Belém logo pegou malária, por isso, não viu seu projeto se realizar. Após 22 anos de Brasil, volta à Suécia, onde morre pouco depois (ALENCAR, 2009, p. 69).

Vingren era formado em Teologia, condição que nenhum outro pastor ligado ao pentecostalismo possuía naquele tempo. Isso em vez de valorizá-lo, ao contrário, atrapalhava porque se dizia que esta formação era uma "fábrica de pastores". Vingren manteve-se contrário à organização de uma convenção nacional que congregaria de forma institucional todas as ADs, mas ela ocorreu assim mesmo em 1930. Vingren era a favor 
do exercício do ministério pelas mulheres, porque conhecia bem os dotes e a atuação da sua esposa.

Assim, Vingren apresenta sua mulher num documento: "Ela tomou a frente dos cultos ao ar livre" (ALENCAR, 2009, p. 73). Isso devia causar grande espanto, pois ela infringia um interdito. O sagrado era para os homens, e o profano era para as mulheres. Estas podiam fazer cultos em suas casas, dentro do cotidiano de suas vidas, cantar nos cultos nas igrejas, mas, no espaço público quem aparecia eram os homens. Por isso, a história oficial não fala de Frida, esta mulher excepcional, mas, falam dela os hinos que compôs, os artigos poesias e jornais que escreveu. Vingren escreve "minha esposa tem levado a responsabilidade da obra" (ALENCAR, 2009, p. 74), portanto, ela liderava os obreiros. Não foi nomeada para isso. Simplesmente tomou a frente. E isto no Rio de Janeiro, capital da república! A igreja crescia muito, e precisava de um pastor. Vingren deixa o Pr. Samuel Nystron (inimigo de Frida, porque detestava mulheres na pregação) em Belém e vem para o Rio. Não há registro de que ela tenha sofrido "violência física", mas como podemos perceber hoje, sofreu uma forte "violência simbólica" (SAFFIOTTI, 2004), pois, marginalizaram-na em vida, e calaram sua memória depois de morta. Tanto dela como das outras mulheres assembleianas. No entanto, em 1925, primeiro ano de seu ministério, ela é consagrada diaconisa, (pelos registros a primeira e a única), mas, oficiosamente havia igrejas dirigidas por mulheres ${ }^{2}$. O hinário das ADs no Brasil, Harpa Cristã, atribui 24 hinos à Frida e mais 16 à outras mulheres, influenciadas por ela, perfazendo o total de 40. Ela foi boicotada, apesar de ter escrito muito mais no jornal do que o marido. Depois da Convenção de 1931, Frida escreve no Mensageiro da Paz 19 artigos e Gunnar apenas 6. Ele sofre por ela não ser reconhecida e valorizada (DANIEL, 2004, p. 76).

O machismo nordestino ligado ao reacionarismo sueco, que Paul Freston chamou de "ethos sueco-nordestino" não podia suportar esta mulher corajosa, destemida, que tudo enfrentava com uma fé forte, com uma cultura invulgar, com uma liderança ímpar, e uma grande capacidade e

2 Há registro de uma polêmica entre missionárias solteiras suecas no Ceará na década de 20 com 0 missionário Bruno Skolimowski, cf. REGO, J. T. Breve histórico da "Assembléia de Deus" no Ceará. Fortaleza: Indústrias Gráficas, 1942 apud ALENCAR, 2009, p. 75. 
preparo espiritual! Ela era muito independente para sua época, pois em 1917 viaja sozinha de navio, da Suécia para os USA e depois para Belém, e tinha uma profissão, era enfermeira formada. Foi a única comentarista mulher das Lições Bíblicas (manual de estudos bíblicos dominicais das ADs) em 100 anos de história! Numa foto oficial da Convenção de 1930 ela aparece sozinha, no meio de 10 homens. Sua luta foi grande, mas não desanimava, apesar da falta de apoio dos obreiros nacionais e dos seus e suas compatriotas. Todos/as se calaram!

Seu filho Ivar, missionário na Argentina, deu uma entrevista a Isael Araújo onde afirma: "Minha mãe tinha o dom de ensinar e pregar como ninguém, e por causa disso sofreu perseguição" (ARAUJO, 1980, p. 254). Sua vida foi uma doação contínua, uma luta pelo crescimento da igreja e pelo protagonismo das mulheres! Ela foi uma grande heroína não reconhecida pela história, pois esta igreja, como quase todas, tem uma historiografia que dá visibilidade apenas aos homens. No mundo religioso, uma mulher não pode aparecer mais que seu marido, e seu cargo precisa ser inferior ao dele.

Chamadas por Deus, ignoradas pelos homens ${ }^{3}$ ! Assim poderia ser considerada a vida desta mulher corajosa, audaciosa, destemida. Ela se sentia chamada por Deus, por isso, não obedecia às pressões humanas. Em 2004 Silas Daniel é o $1^{\circ}$ autor a lhe dar destaque, "considerando-a uma das mais preparadas evangélicas que já pisaram o solo brasileiro" (DANIEL, 2004, p. 76). Infelizmente, isto ainda é pouco conhecido.

Em setembro de 1930, em Natal-RN, aconteceu a $1^{\text {a }}$ Convenção das ADs do Brasil para discutir vários problemas, mas o principal era a atuação das mulheres na igreja.

As irmãs têm todo o direito de participar na obra evangélica, testificando de Jesus e sua salvação, e também ensinando quando for necessário. Mas não se considera justo que uma irmã tenha a função de pastor de uma igreja ou ensinadora, salvo em casos excepcionais mencionados em Mateus 12,3-8. Assim deve ser somente quando não existam na igreja irmãos capacitados para pastorear ou ensinar" (VINGREN, 1982, p. 77).

3 Laura Sá Aragão escreveu uma dissertação de mestrado com este título Chamadas por Deus, ignoradas pelos homens. Reducionismo cultural em relação ao trabalho missionário feminino, fruto da sua dissertação de Mestrado no CEM em 2004. Cf. ARAGÃO, 2004.

Rev. Pistis Prax., Teol. Pastor., Curitiba, v. 10, n. 3, 722-741, set./dez. 2018 
Esta declaração nos faz perceber: primeiro, na época existiam mulheres pastoreando, caso contrário, seria desnecessária a proibição; segundo, apesar da proibição se mantém a possibilidade da exceção, no caso de necessidade, isto é, na ausência de “irmãos capacitados". Ora, na década de 30, com a expansão da $\mathrm{AD}$, não havia número suficiente de irmãos capacitados para atender todas as igrejas em todas as cidades do Brasil. E a maioria dos pastores não tinha o seu conhecimento, sua capacidade. Por isso, as mulheres viviam sua vocação, seu chamado, sua missão sem publicidade.

As críticas mais ferrenhas feitas ao pentecostalismo no início do século se deviam ao fato de ser um movimento de liderança negra e feminina (HOLLENWEGER, 1976), o que nós hoje valorizamos! Ao racismo da época, nos EUA, unia-se o fato de serem mulheres! No entanto, a interpretação teológica afirmava que o "Espírito Santo concede seus dons a todos(as), sem exceção". Desde o início do movimento da Rua Azuza havia mulheres pregando e exercendo o ministério pastoral. E com este trabalho, não considerado nem valorizado, a igreja crescia e se expandia. John Ongman (1845-1931), um dos líderes do pentecostalismo sueco, em 1900, ao escrever um livreto intitulado $O$ direito da mulher pregar o evangelho é dos poucos que ousava se expressar a favor delas e a valorizar o ministério das mulheres! (ALENCAR, 2009, p. 78).

Este é um ponto difícil quer seja na Suécia, nos EUA ou no Brasil. No princípio do movimento, em todos os três lugares, as mulheres tinham espaço, títulos, cargos e liberdade para exercerem o ministério, mas quando o movimento se consolida são marginalizadas. A partir da década de 30, elas começam a sofrer restrições. Embora, privadamente, continuassem a exercer a vocação a que se sentiam chamadas.

Frida não aceita a determinação da Convenção de 1930, e escreve um texto no Mensageiro da Paz mobilizando as assembleianas a entrarem na guerra. As mulheres foram proibidas de falar, mas não de escrever, e Frida elabora um texto antológico, conclamando as mulheres a não se deixarem dominar:

Despertemo-nos para atender o chamado do Rei, alistando-nos nas Suas fileiras. As irmãs das "Assembléias de Deus" que igualmente, como os irmãos tem recebido o Espírito Santo, e portanto, possuem a mesma 
responsabilidade de levar a mensagem aos pecadores precisam convencer-se de que podem mais do que tratar dos deveres domésticos. Sim, podem, também, quando chamadas pelo Espírito Santo sair e anunciar o Evangelho. Em todas as partes do mundo, e especialmente no trabalho pentecostal, as irmãs tomam grande parte na evangelização. Na Suécia, país pequeno de 7 milhões de habitantes, existe um grande número de irmãs trabalhando exclusivamente no Evangelho. Dirigem cultos, testificam, e falam da Palavra. Por que razão, as irmãs brasileiras hão de ficar atrasadas? Será, que o campo não chega, ou que Deus não quer? Creio que não. Será falta de coragem? As irmãs, convém buscarem santificação e consagração, para que o Senhor as possa dirigir e abençoar. Não há tempo a perder. Jesus vem em breve. O Senhor diz: "A quem enviarei, e quem há de ir por nós? Diremos nos: "Eis-me aqui, envia-me a mim (ALENCAR, 2009, p. 80).

Alencar, buscando colocar mais luz sobre a figura desta mulher ímpar se pergunta: quem na liderança assembleiana-sueca ou brasileira, seria capaz de responder a este texto? Ele mesmo responde demonstrando a esperteza de Frida. Ela parte da realidade, no período entre guerras, para articular a necessidade de mão-de-obra. Seu título: "despertemos para atender ao chamado do Rei" atrai corações e mentes, de modo que, convoca para uma guerra divina, que é a mais importante.

Não se opõe aos fazeres domésticos, mas, afirma que podem fazer mais. E acima de tudo, a argumentação bíblica é fundamental: o Espírito Santo age igualmente nas irmãs e nos irmãos. Numa sociedade, como a brasileira, onde as mulheres ainda não votavam ela ousava afirmar a igualdade feminina. Se na Suécia as mulheres estavam trabalhando exclusivamente na obra, porque as brasileiras deveriam ficar atrás? Termina o texto com o escatologismo típico da época: "não há tempo a perder. Jesus vem em breve", e proclama o grande final, o grande chamamento e a resposta que devem dar os/as missionários/as; "a quem enviarei ... eis-me aqui, envia-me a mim".

Claro que este texto extraordinário causa grandes problemas para ela, para o marido, para a igreja local, e para as demais igrejas no Brasil onde o jornal é lido! Na convenção de 1930 não se fala em Vingren deixar o Brasil, ao contrário, se oficializa a sua liderança sueca no sul e a brasileira no norte e nordeste; mas, dois anos depois muito doente, e provavelmente desgostoso com o tratamento dado à esposa, deixa o Brasil voltando para a Suécia. 
Apesar de serem mencionados sempre como fundadores Berg e Vingren, sempre foram voto vencido na instituição. Frida foi a grande diferença em termos de liderança. Irônico que, apesar disso, em 1930 a possibilidade das mulheres pastorearem poderia existir, apenas se não tivessem irmãos preparados. O assunto volta à discussão na convenção de 1983, é rejeitado por unanimidade. Na convenção de Brasília em 2001 o tema da possibilidade das mulheres exercerem o ministério volta e, de novo, é rejeitado por um grande número. Mas, na calada elas continuavam. Portanto, mesmo oficialmente rejeitado, oficiosamente, as mulheres continuam exercendo seu ministério construindo a igreja, pregando, orando, evangelizando, enfim, vivendo a missão.

\section{Conclusão: por um centro com cara de margem: as pro-vocações que vêm desde os lugares (teológicos) marginais}

O pentecostalismo em sua trajetória, das margens das margens rumo aos centros sócio-eclesiais, tem um enorme potencial de nos pro-vocar, de propor uma experiência renovada de nossa vocação de filhas e filhos de Deus, irmãs e irmãos de Jesus. Ele vem nos chamar a vivenciar a fé onde estamos (nós teólogas e teólogos geralmente nos encontramos nos centros), transformando tais lugares, dando-lhes feições de margem, sobretudo, naquilo que há de fértil e capaz da novidade. Um centro com cara de margem, capaz de recuperar uma gnosiologia compreensiva, uma teologia efetiva e afetiva, uma eclesiologia igualitária etc. Para isso, é necessário aguçar a capacidade de crítica das imagens em meio a uma civilização imagética, para discernir imagens inspiradoras e renovadoras.

É das margens que emerge o advento do novo, daquilo que não foi esterilizado pelos acessos de uma institucionalização e de seus vícios hierarquizadores, masculinizadores, embranquecedores, racionalizadores... Das margens fluem criatividade para enfrentar a banalização das imagens inflacionadas em nosso tempo. Das margens nos pode chegar a coragem de um Seymour, a intrepidez de uma Frida. Das margens aguardamos o sopro do Espírito que virá sobre "toda a carne". 


\section{Referências}

ALENCAR, G. F. Frida Vingren (1891-1940): quando uma missão vale mais do que a vida. In: OROZCO, Y. P. (Org.). Religiões em diálogo: violência entre as mulheres. São Paulo: Católicas pelo direito de decidir, 2009.

ARAGÃO, L. S. Chamadas por Deus, ignoradas pelos homens. Reducionismo cultural em relação ao trabalho missionário feminino. Dissertação (Mestrado em Teologia) - Centro Evangélico de Missões (CEM), Viçosa, 2004.

ARAUJO, I. Dicionário do Movimento Pentecostal. Rio de Janeiro: CPAD, 1980.

BURGARD, P. J. Retórica magistral - a lógica da autoridade e da sujeição em Lutero. In: HELMER, C. (Ed.). Lutero, um teólogo para o tempo presente. São Leopoldo: Sinodal, 2013. p. 295-313.

DANIEL, S. (Org.). História da Convenção geral das Assembléias de Deus no Brasil. Rio de Janeiro: CPAD, 2004.

DURAND, G. Champs de l'imaginaire. Grenoble: Ellug, 1996.

DURAND, G. O imaginário. Ensaios acerca das ciências e da filosofia da imagem. Rio de Janeiro: DIFEL, 1998.

DURAND, G. As estruturas antropológicas do imaginário. São Paulo: Martins Fontes, 2002.

HOLLENWEGER, W. El Pentecostalismo - historia e doctrinas. Buenos Aires: La aurora, 1976.

LUTERO, M. Obras Selecionadas. v. 2. Sobre a liberdade cristã. São Leopoldo: Sinodal. Porto Alegre: Concórdia, 2000.

MAFFESOLI, M. Elogio da razão sensível. Petrópolis: Vozes, 2003.

MÁRQUEZ-FERNÁNDEZ, A. B. Pensar com os sentimentos: razão, escuta, diálogo, corpo e liberdade. Nova Petrópolis: Nova Harmonia; Venezuela: ÚNICA, 2014. 
MENDONÇA, A. G.; VELASQUES, P. Introdução ao protestantismo no Brasil. São Paulo: Loyola, 1990.

OLIVEIRA, D. M. El sacerdocio, el obispado y el papado de todas las personas creyentes. In: BULLÓN, F.; PANOTTO, N. (Orgs.). Hacia dónde vá el protestantismo en América Latina? Una visión multidisciplinaria y prospectiva a los 500 años de la Reforma. Buenos Aires-Argentina: Ediciones Kairós, 2017. p. 131-140.

OLIVEIRA, D. M.; TERRA, K. R. C. Êxtase como locus hermenêutico na Experiência Religiosa dos Pentecostalismos. Revista Brasileira de História das Religiões, a. XI, p. 41-62, 2018.

REGO, J. T. Breve histórico da "Assembléia de Deus" no Ceará. Fortaleza: Indústrias Gráficas, 1942.

ROCHA, A. Surgimento e conseqüências do pentecostalismo. Revista Compromisso, Rio de Janeiro, a. XII, n. 44, p. 76-80, jan./mar. 2003.

ROCHA, A. Espírito Santo. Aspectos de uma pneumatologia solidária à condição humana. São Paulo: Vida, 2008.

SAFFIOTI, H. I. B. Gênero, Patriarcado, Violência. São Paulo: Editora Fundação Perseu Abramo, 2004. p. 79-80.

SEYMOUR, W. O avivamento da Rua Azuza. Rio de Janeiro: CPAD, 2001.

SHAULL, R.; CESAR, W. Pentecostalismo e o futuro das Igrejas cristãs. Petrópolis: Vozes, 2000.

VINGREN, G. O diário de um pioneiro. Rio de Janeiro: CPAD, 1982.

Recebido: 19/09/2018

Received: 09/19/2018

Aprovado: $25 / 10 / 2018$

Approved: 10/25/2018 